\title{
PERTUMBUHAN DAN KANDUNGAN KARAGINAN RUMPUT LAUT Kappaphycus alvarezii PADA DOSIS MIKROORGANISME LOKAL (MOL) BUAH MAJA
}

\author{
Yanti Mutalib $^{\left.1^{*}\right)}$, Samsu Adi Rahman ${ }^{2)}$ \\ ${ }^{1,2)}$ Program Studi Budidaya Perairan, Fakultas Perikanan, Universitas \\ Muhammadiyah, Luwuk, 94711 \\ *E-mail: yantimutalib@ymail.com
}

Diterima: 22 Agustus 2017/Disetujui: 28 Desember 2017

\begin{abstract}
ABSTRAK
Penelitian ini dilaksanakan di Desa Jaya Bakti Kecamatan Pagimana Kabupaten Banggai, Propinsi Sulawesi Tengah. Organisme uji yang digunakan yaitu rumput laut Kappaphycus alvarezii yang diambil dari hasil budidaya masyarakat di sekitar lokasi penelitian. Berat awal organisme uji yang digunakan yaitu $100 \mathrm{~g}$. Sedangkan bahan uji mol buah maja adalah hasil permentasi selama seminggu dan telah dilakukan penyaringan. Rancangan yang digunakan dalam penelitian ini adalah Rancangan Acak Lengkap (RAL) dengan tiga perlakuan dan tiga ulangan, sehingga jumlah unit percobaan adalah sembilan satuan percobaan. Perlakuan A = Dosis Mol 0.5 L/10 L air, B = Dosis Mol 1 L/10 L air dan C = Dosis Mol 1.5 L/10 L air. Parameter yang diamati adalah pertumbuhan berat mutlak, laju pertumbuhan spesifik harian dan kandungan karginan. Data kualitas air meliputi pengukuran suhu dan salinitas. Pengukuran salinitas dan suhu dilakukan setiap hari yaitu pagi dan sore hari. Pengukuran kecepatan arus dilakukan setiap dua minggu (setiap pagi dan sore hari). Untuk mengetahui pengaruh perlakuan digunakan Analisis Ragam (Anova) dengan menggunakan prog SPSS versi 19 (Statistical Package for Social Sciences). Bila terjadi perbedaan di antara perlakuan dilanjutkan dengan uji BNT. Hasil penelitian menunjukan bahwa Pada Pertumbuhan Berat Mutlak diperoleh hasil yang tertinggi pada perlakuan C $(1.5 \mathrm{~L} / 10 \mathrm{~L}$ air). Pada Pertumbuhan Spesifik Harian memperlihatkan bahwa rata-rata laju pertumbuhan spesifik harian (\%) yang tertinggi yaitu pada perlakuan C (1.5 L/10 L air) dengan nilai $3.8 \%$ minggu ketiga. Nilai Kandungan Karagenan memperlihatkan bahwa kandungan karagenan pada rumput laut $K$. alvarezii tertinggi, yaitu pada perlakuan C (1.5 L/10 L air) minggu keempat dengan nilai $43.3 \%$.
\end{abstract}

Kata kunci: karaginan, maja, mol, pertumbuhan, rumput laut

\section{PENDAHULUAN}

Rumput laut (sea weeds) atau yang biasa juga disebut ganggang (algae) merupakan tumbuhan berklorofil dimana seluruh bagian tanaman dapat menyerupai akar, batang, daun, atau buah semuanya disebut talus.

Seiring kebutuhan rumput laut yang semakin meningkat, baik untuk memenuhi kebutuhan dalam negeri maupun luar negeri, sekaligus memperbesar devisa negara dari sektor non-migas, maka cara terbaik untuk tidak selalu 
menggantungkan persediaan dari alam adalah dengan melakukan budidaya rumput laut. Hingga saat ini, produksi rumput laut sangat besar didukung oleh budidaya.

Salah satu aspek yang mendukung produksi rumput laut adalah dengan pemberian unsur hara dan peningkatan organisme pendukung yang mempercepat pertumbuhan rumput laut, yaitu mikroorganisme lokal (mol).

Menurut Anonim (2013), mol adalah larutan hasil fermentasi yang berbahan dasar dari berbagai sumberdaya yang mudah diperoleh. Larutan mol mengandung hara mikro, makro dan bakteri yang berpotensi sebagai dekomposer, perangsang tumbuhan, agen pengendali hama atau penyakit dan pestisida organik terutama sebagai fungisida. Dosis yang digunakan pada semua jenis tumbuhan yaitu $1 \mathrm{~L} \mathrm{~mol}$ : 10 L air.

Berdasarkan fungsi dari mol tersebut sangatlah tepat diterapkan pada rumput laut untuk meningkatkan kandungan karaginan dan pertumbuhannya, maka dilakukan penelitian tentang "Analisis Kandungan Karaginan dan Pertumbuhan Rumput Laut $K$. alvarezii dengan dosis mikroorganisme lokal (mol) Buah Maja yang Berbeda". Diharapkan penelitian ini dapat memberikan informasi tentang kandungan karaginan dan pertumbuhan rumput laut $K$. alvarezii dengan pemberian mol buah maja yang berbeda.

Penelitian ini bertujuan Untuk melihat pengaruh mol buah maja terhadap kandungan karaginan dan pertumbuhan rumput laut $K$. alvarezii serta menganalisis dosis mol buah maja yang tepat bagi peningkatan karaginan dan pertumbuhan rumput laut $K$. alvarezii.

\section{BAHAN DAN METODE}

Penelitian ini akan dilaksanakan di Desa Jaya Bakti Kecamatan Pagimana Kabupaten Banggai, Propinsi Sulawesi Tengah.

Alat yang akan digunakan pada penelitian ini yaitu tali induk, pemberat, pelampung induk, pelampung ris, tali jangkar sebagai media budidaya, secchi disck, layangan arus, refraktometer, termometer, $\mathrm{pH}$ meter digunakan sebagai alat pendukung untuk mengukur kualitas air dan timbangan digital untuk menimbang bobot rumput laut. Sedangkan bahan yang akan digunakan yaitu rumput laut $K$. alvarezii sebagai organisme uji, tali rapia untuk mengikat organisme uji dan mol buah maja.

Organisme yang akan digunakan yaitu rumput laut $K$. alvarezii yang diambil dari hasil budidaya masyarakat di sekitar lokasi penelitian. Berat awal organisme uji yang digunakan yaitu $100 \mathrm{~g}$. Sedangkan bahan uji mol buah maja adalah hasil permentasi selama seminggu dan telah dilakukan penyaringan.

Rancangan yang digunakan dalam penelitian ini adalah Rancangan Acak Lengkap (RAL) dengan Empat perlakuan dan tiga ulangan, sehingga jumlah unit percobaan adalah dua belas satuan percobaan.

Perlakuan A = Dosis mol 0.5 L/10 L air, Perlakuan B = Dosis mol $1 \mathrm{~L} / 10 \mathrm{~L}$ air dan Perlakuan $\mathrm{C}=$ Dosis mol 1.5 L/10 L air.

Parameter yang diamati meliputi laju pertumbuhan spesifik harian, pertumbuhan mutlak, salinitas, suhu, arus dan kedalaman.

Pertumbuhan berat mutlak rumput laut dihitung dengan menggunakan rumus Effendie (1979): 


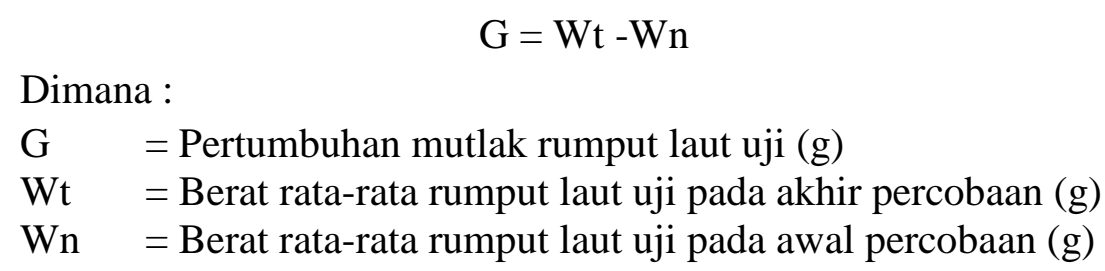

\section{Laju pertumbuhan spesifik harian}

Untuk mengetahui laju pertumbuhan spesifik harian maka digunakan rumus (Zonneveld, 1991).

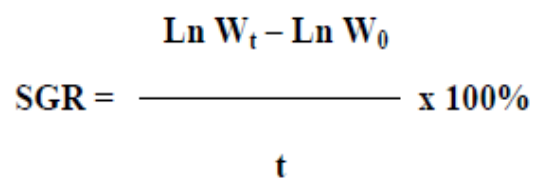

Dimana:

SGR = Laju pertumbuhan spesifik harian $(\%)$

$\mathrm{W}_{\mathrm{t}} \quad=$ Berat rata-rata rumput laut uji pada akhir percobaan $(\mathrm{g})$

$\mathrm{W}_{0} \quad=$ Berat rata-rata rumput laut uji pada awal percobaan $(\mathrm{g})$

$\mathrm{t} \quad=$ Lama pemeliharaan (hari)

Untuk mengetahui kandungan karaginan rumput laut K.alvarezii setiap perlakuan diukur di Laboratorium Fakultas Perikanan Universitas Hasanuddin Makassar setiap minggu.

Data kualitas air meliputi pengukuran suhu dan salinitas. Pengukuran salinitas dan suhu dilakukan setiap hari yaitu pagi dan sore hari. Pengukuran kecepatan arus dilakukan setiap dua minggu (setiap pagi dan sore hari).

\section{HASIL DAN PEMBAHASAN}

\section{Pertumbuhan Berat Mutlak Rumput Laut}

Dalam penelitian ini diperoleh pertumbuhan rumput laut $K$. alvarezii dengan dosis yang berbeda pada mol buah maja dengan berat awal (100 g) dan masa pemeliharaan selama sebulan dengan perhitungan empat minggu atau selama 30 hari dengan menggunakan rumus perhitungan Pertumbuhan Berat Mutlak (Effendie, 1979) maka diperoleh hasil sesuai dengan tabel di bawah ini :

Tabel 1. Pertumbuhan berat mutlak rumput laut $K$. alvarezii dengan dosis berbeda pada mol buah maja selama 30 hari (4 Minggu)

\begin{tabular}{lllll}
\hline \multirow{2}{*}{ Perlakuan } & \multicolumn{4}{c}{ Minggu $(\mathrm{g})$} \\
\cline { 2 - 5 } & 1 & 2 & 3 & 4 \\
\hline $\mathrm{A}$ & 16 & 89 & 174 & 153 \\
$\mathrm{~B}$ & 45 & 115 & 210 & 110 \\
$\mathrm{C}$ & 110 & 176 & 215 & 125 \\
\hline
\end{tabular}

Berdasarkan tabel di atas memperlihatkan bahwa pada perlakuan A $(0.5$ L/10 L air) memiliki pertumbuhan berat mutlak, yaitu $16 \mathrm{~g}, 89 \mathrm{~g}$ dan $174 \mathrm{~g}$ pada minggu (I, II, III) dan mengalami penurunan pada minggu keempat (153 g). Sedangkan pada perlakuan B (1 L /10 L air) pada minggu (I, II,III) juga mengalami peningkatan lebih tinggi menjadi $45 \mathrm{~g}, 115 \mathrm{~g}, 210 \mathrm{~g}$ dan kembali mengalami 
penurunan pada minggu keempat $(110 \mathrm{~g})$. Hal tersebut juga terjadi pada perlakuan $\mathrm{C}(1.5 \mathrm{~L} / 10 \mathrm{~L}$ air) yang terus menerus mengalami peningkatan tertinggi menjadi $110 \mathrm{~g}, 176 \mathrm{~g}, 215 \mathrm{~g}$ dan mengalami penurunan pada minggu keempat (125 g). Hal ini sesuai dengan pendapat Mondoringin, et al., (2013), berat awal rumput laut yang akan dibudidaya dapat berpengaruh terhadap pertumbuhannya, dimana bibit dengan awalnya lebih kecil akan memberikan hasil pertumbuhan yang lebih cepat karena tidak terjadi persaingan antra thallus dalam mendapatkan makanan.

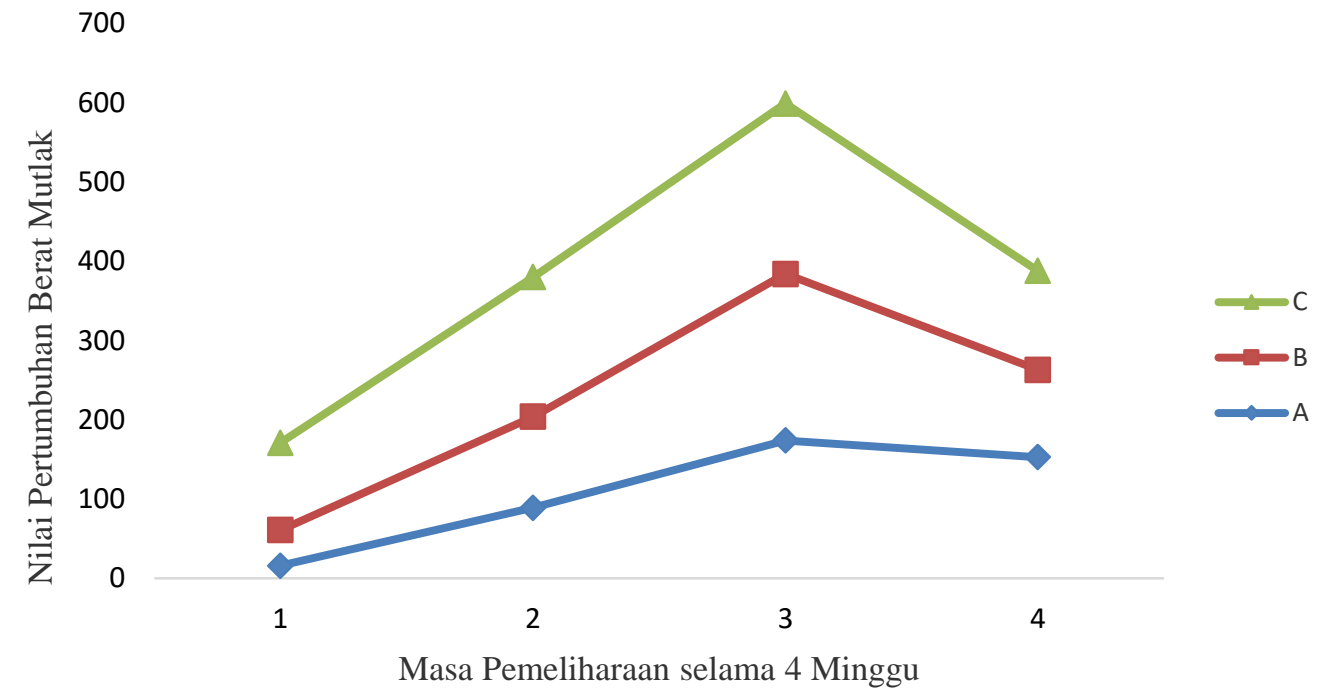

Gambar 1. Grafik pertumbuhan berat mutlak

Berdasarkan (Gambar 3) di atas menjelaskan bahwa pertumbuhan mutlak tertinggi berada pada perlakuan C $(1.5 \mathrm{~L} / 10 \mathrm{~L}$ air) dengan jarak tanam yang sama $20 \mathrm{~cm}$ untuk semua perlakuan dan hasil yang diperoleh nilai $215 \mathrm{~g}$ pada minggu ketiga, Sedangkan pertumbuhan mutlak terendah pada perlakuan A $(0.5 \mathrm{~L} / 10 \mathrm{~L}$ air $)$ dengan nilai $102 \mathrm{~g}$. Berdasarkan hasil uji Anova diperoleh perbedaan yang nyata ( $\mathrm{p}$ $<0.05$ ) pada perlakuan dosis mol buah maja yang berbeda terhadap pertumbuhan berat mutlak rumput laut $K$. alvarezii. Hal ini berarti perbedaan dosis mol buah maja yang berbeda memberikan pengaruh yang signifikan terhadap pertumbuhan berat mutlak rumput laut $K$. alvarezii.

Hal ini diduga karena pemberian mol buah maja yang sesuai dengan jumlah dosisnya. Semakin tinggi dosis yang diberikan maka nilai pertumbuhan mutlak pun meningkat dan seiring dengan fase pertumbuhan pada rumput laut. Hasil di atas dapat dikategorikan bahwa mol buah maja bekerja dengan baik karena dapat memicu pertumbuhan mutlak pada rumput laut $K$. alvarezii meningkat karena komponen kimia tanin yang terdapat pada buah maja dapat dimanfaatkan sebagai obat.

\section{Laju Pertumbuhan Spesifik Harian}

Rata-rata laju pertumbuhan spesifik harian (\%) rumput laut yang dipelihara selama empat minggu pada setiap perlakuan disajikan pada (Tabel 2). 
Tabel 2. Rata-rata laju pertumbuhan spesifik harian (\%) rumput laut $K$. alvarezii

\begin{tabular}{ccccc}
\hline \multirow{2}{*}{ Perlakuan } & \multicolumn{5}{c}{ Minggu (\%) } \\
\cline { 2 - 5 } & I & II & III & IV \\
\hline A & 0.5 & 2.1 & 3.4 & 3.1 \\
B & 1.2 & 2.6 & 3.8 & 2.5 \\
C & 2.5 & 3.4 & 3.8 & 2.7 \\
\hline
\end{tabular}

Berdasarkan (Tabel 2) dan (Gambar 2) memperlihatkan bahwa rata-rata laju pertumbuhan spesifik harian (\%) yang tertinggi yaitu pada perlakuan $\mathrm{C}(1.5 \mathrm{~L} / 10 \mathrm{~L}$ air) dengan nilai $3.8 \%$ minggu ketiga dan rata - rata laju pertumbuhan spesifik harian $(\%)$ yang terendah pada perlakuan A $(0.5 \mathrm{~L} / 10 \mathrm{~L})$ dengan nilai $0.5 \%$ pada minggu pertama. Akan tetapi pada minggu keempat laju pertumbuhan spesifik harian (\%) mengalami penurunan. Menurunnya laju pertumbuhan spesifik dikarenakan rendahnya tingkat pertumbuhan yaitu adanya penambahan bobot thallus yang lebih rendah seiring dengan pertambahan usia pemeliharaan rumput laut yang menyebabkan terjadinya persaingan dalam memperoleh unsur hara dan penyerapan sinar matahari dalam proses fotosintesis, sehingga laju pertumbuhan rumput laut semakin menurun.

Sesuai dengan hasil uji Anova diperoleh perbedaan yang nyata $(\mathrm{p}<0.05)$ pada perlakuan dosis mol buah maja yang berbeda terhadap pertumbuhan berat spesifik rumput laut $K$. alvarezii. Hal ini berarti perbedaan dosis mol buah maja yang berbeda memberikan pengaruh yang signifikan terhadap pertumbuhan berat spesifik pada rumput laut $K$. alvarezii.

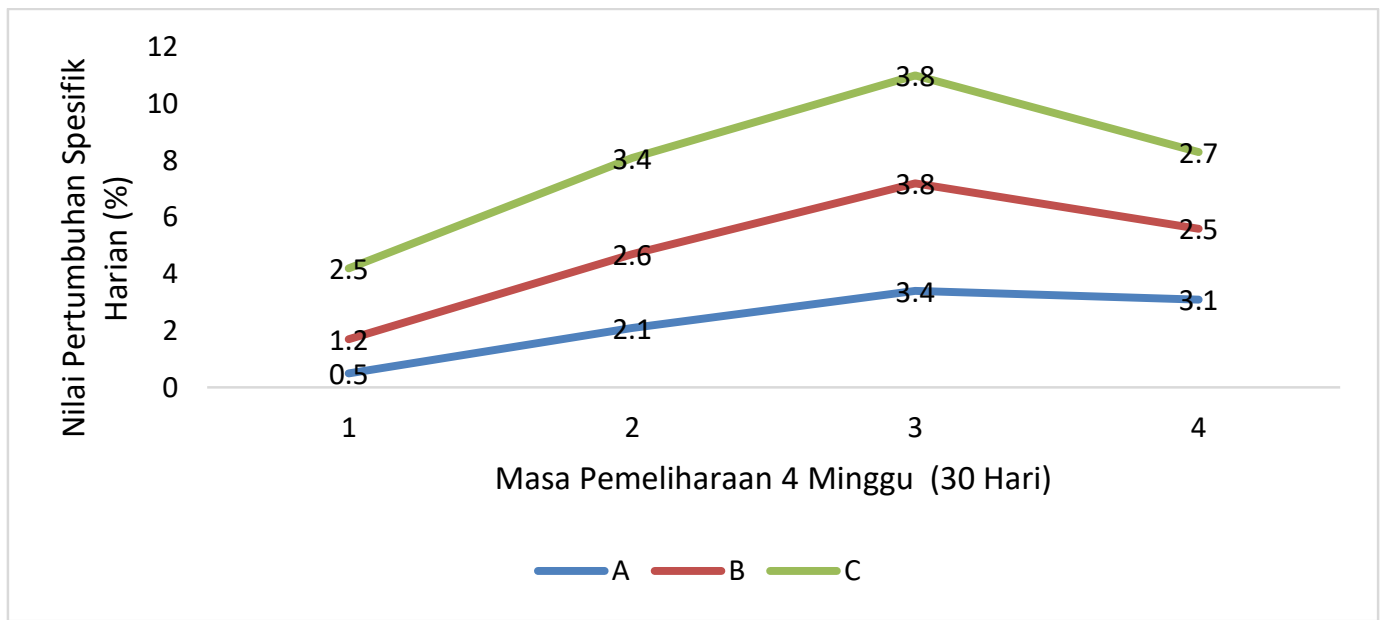

Gambar 2. Grafik pertumbuhan spesifik harian

Menurut Yusnaini et al. (2000) bahwa penurunan laju pertumbuhan spesifik diduga akibat cepatnya terjadi kejenuhan pembelahan sel. Rumput laut yang telah mengalami proses adaptasi kemudian mengalami fase pertumbuhan yang cepat dan kemudian terjadi penurunan kemampuan pertumbuhan sel menyebabkan pertumbuhan lambat. 


\section{Kandungan Karagenan}

Hasil perhitungan kandungan karagenan pada rumput laut $K$. alvarezii adalah tercantum pada (Tabel 3) di bawah ini:

Tabel 3. Kandungan karagenan pada rumput laut $K$. alvarezii

\begin{tabular}{ccccc}
\hline \multirow{2}{*}{ Perlakuan } & \multicolumn{4}{c}{ Minggu (\%) } \\
\cline { 2 - 5 } & I & II & III & IV \\
\hline A & 12.7 & 23.2 & 26.7 & 30.8 \\
B & 17.8 & 19.2 & 28.3 & 31.7 \\
C & 32.2 & 34.3 & 36.5 & 43.3 \\
\hline
\end{tabular}

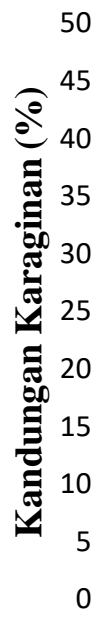

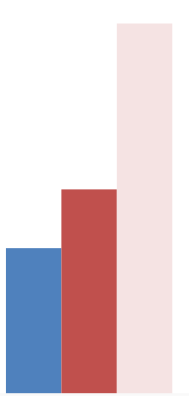

1

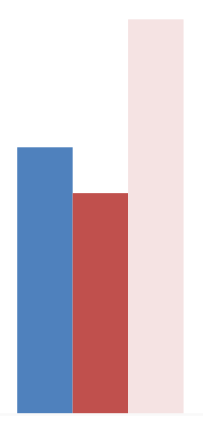

2

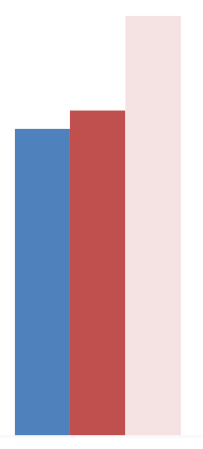

3

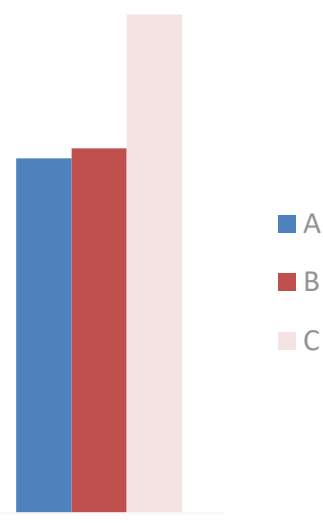

4

Masa Pemeliharaan Rumput Laut (30 Hari

Gambar 3. Kandungan rumput laut $K$. alvarezii

Pada (Tabel 3) dan (Gambar 3) di atas memperlihatkan bahwa kandungan karagenan pada rumput laut $K$. alvarezii tertinggi yaitu pada perlakuan C (1.5 L/10 $\mathrm{L}$ air) Minggu keempat dengan nilai $43.3 \%$. Sedangkan nilai terendah pada perlakuan A (0.5 L/10 L air) minggu pertama dengan nilai $12.7 \%$.

Hasil uji Anova diperoleh perbedaan yang nyata $(\mathrm{p}<0.05)$ pada perlakuan dosis mol buah maja yang berbeda terhadap karagenan rumput laut $K$. alvarezii. Hal ini berarti perbedaan dosis mol buah maja yang berbeda memberikan pengaruh yang signifikan terhadap karagenen rumput laut $K$. alvarezii.

Kandungan nilai karagenan meningkat sesuai dengan jumlah dosis mol buah Maja yang diberikan. Hal ini dapat dikatakan bahwa mol buah maja dapat memicu peningkatan kandungan karaginan pada rumput laut $K$. alvarezii. Hasil yang diperoleh ini hampir sama dengan nilai yang diperoleh oleh Rao et al., (2008) bahwa Kandungan karaginan dalam rumput laut berkisar $42.42 \% \pm 1.89 \%$ hingga $58.36 \% \pm 1.26 \%$. Nilai kandungan karagenan dalam penelitian ini meningkat sesuai dengan lama waktu pemeliharaan. Hal ini disebabkan karena pembentukan karagenan optimal dimulai pada minggu ke- 4. Menurut Sulistijo (2002), bahwa 
kualitas tanaman rumput laut $K$. alvarezii selama penanaman menunjukkan bahwa tanaman berumur mulai 4 minggu atau satu bulan sudah memberikan mutu yang memenuhi syarat untuk keperluan industri karagenan. Mutu standar kandungan karagenan untuk perdagangan rumput laut minimal 30\%.

Hasil ini juga diduga karena efek dari pemberian mol buah maja sebagaimana yang diketahui bahwa buah maja memiliki nilai kandungan tanin yang sangat tinggi. Hal ini didukung oleh Prawesty (2001) mengemukakan bahwa Tannin adalah metabolit sekunder tanaman yang bersifat astrigen dengan rasa khas yang sepat. Tannin secara ilmiah didefinisikan sebagai senyawa poliphenol yang mempunyai berat molekul tinggi dan memiliki gugus hidroksil dan gugus lainnya sehingga dapat membentuk kompleks dengan protein dan makromolekul lainnya.

\section{Parameter Kualitas Air}

Berdasarkan penelitian di atas diperoleh nilai suhu yang optimal atau stabil selama masa pemeliharaan sehingga memperoleh nilai pertumbuhan yang baik juga. Hal ini di dukung oleh penelitian sebelumnya bahwa Rumput laut hidup dan tumbuh pada perairan dengan kisaran suhu air antara $20-28{ }^{\circ} \mathrm{C}$, namun masih ditemukan tumbuh pada suhu $31^{\circ} \mathrm{C}$ (Direktorat Jenderal Perikanan, 1990).

Sebagaimana di perairan kisaran salinitas yang normal adalah 28-32 ppm (Dahuri et al, 1996). Sedangkan pada lokasi budidaya rumput laut K. alvarezii memiliki kisaran salinitas antara 26-33 ppm. Menurut Anggadinedja et al, (2006) Lokasi budidaya diusahakan yang jauh dari sumber air tawar seperti dekat muara sungai karena dapat menurunkan salinitas air itu sebabnya salinitas pada stasiun III rendah karena perairan dipengaruhi suplai air tawar dari aliran sungai.

Kisaran kecepatan arus yang diperoleh dalam penelitian termasuk kategori baik atau kecepatan arus yang cepat. Hasil penelitian ini sesuai dengan pendapat Mason (1981) dalam Mariska (2007), mengelompokkan perairan berarus sangat cepat $(>1 \mathrm{~m} / \mathrm{dtk})$, cepat $(0.5-1 \mathrm{~m} / \mathrm{dtk})$, sedang $(0.25-0.5 \mathrm{~m} / \mathrm{dtk})$, lambat $(0.1-0.2$ $\mathrm{m} / \mathrm{dtk})$ dan sangat lambat $(<0.1 \mathrm{~m} / \mathrm{dtk})$. Gerakan air berfungsi untuk mensuplay zat hara juga membantu memudahkan rumput laut menyerap zat hara, melangsungkan pertukaran oksigen.

\section{KESIMPULAN}

Penelitian ini dapat disimpulkan, yaitu pertumbuhan berat mutlak diperoleh hasil yang tertinggi pada perlakuan $\mathrm{C}(1.5 \mathrm{~L} / 10 \mathrm{~L}$ air $)$, perlakuan ini dianggap memenuhi kebutuhan unsur hara pertumbuhan rumput laut Kappaphycus alvarezii. Pertumbuhan spesifik harian memperlihatkan bahwa rata-rata laju pertumbuhan spesifik harian (\%) yang tertinggi, yaitu pada perlakuan $\mathrm{C}(1.5 \mathrm{~L} / 10 \mathrm{~L}$ air) dengan nilai $3.8 \%$ minggu ktiga. Nilai kandungan karagenan rumput laut tertinggi, yaitu pada perlakuan C (1.5 L/10 L air) minggu keempat dengan nilai $43.3 \%$, sedangkan parameter yang paling berpengaruh terhadap pertumbuhan rumput laut dan konsentasi karagian, yaitu suhu, salinitas dan kecepatan arus yang tinggi, sehingga menghasilkan kualitas karaginan yang baik. 


\section{UCAPAN TERIMA KASIH}

Ucapan terima kasih kepada Lembaga Penelitian, Pengembangan dan Pengabdian Kepada Masyarakat (LP3M) Universitas Muhammadiyah Luwuk yang telah memberikan bantuan dana untuk kelancaran penelitian ini.

\section{DAFTAR PUSTAKA}

Anggadireja JT, Zatnika A, Purwoto H, Istini S. 2006. Rumput Laut. Pembudidayaan, Pengolahan dan Pemasaran Komoditas Perikanan Potensial. Penebar Swadaya. Jakarta.

Anonim. 2013. Manfaat Buah Maja. http://manfaat-buahsegar. blogspot.com/2013/08/manfaat-buah-maja.html (diakses: 25 April 2014)

Dahuri R.1996. Pengelolaan Sumberdaya Wilayah Pesisir dan Lautan Secara Terpadu. Jakarta : PT. Pradnya Paramita.

Effendie MI. 1979. Metode Biologi Perikanan. Yayasan Dewi Sri. Bogor. $112 \mathrm{Hal}$ Mariska I. 2007. Penentuan Pola Sebaran Makrozoobentos Berdasarkan Kedalaman Di Perairan Teluk Labuange, Kabupaten Barru. (Skripsi) Ilmu Kelautan. FIKP-Unhas. Makassar.

Mondoringin L, Tiwa RB, Salindeho I. 2013. Pertumbuhan Rumput Laut Kappaphycus alvarezii pada Perbedaan Kedalaman dan Berat Awal di Perairan Talengen Kabupaten Kepulauan Sangihe. Laporan Penelitian. Sulawesi Utara.

Prawesty N. 2001. Tannin. Available at http://nikenprawesty.blogspot.com/ diakses 21 juli 2014.

Rao SV, Shao J. 2008, Self-nanoemulsifying drug delivery systems (SNEDDS) for oral delivery of protein drugs: I. Formulation development, Int. J. Pharm., 362(1-2):2-9.

Sulistijo. 2002. Budidaya Rumput Laut. (www. google.com)

Yusnaini, Ramli, Pangerang UK. 2000. Budidaya Intensif Teripang Pasir Holothuria scabra dengan Menggunakan Alga Eucheuma cottoni Sebagai Shelter. Laporan HasilPenelitian Lembaga Penelitian. Universitas Haluoleo. Kendari 50 hal.

Zonneveld N, Huisman EA, Boon JH. 1991. Prinsip-prinsip Budidaya Ikan. Penerbit PT Gedia Pustaka Utama, Jakarta. 318 hlm. 